\title{
Study on Education Strategy of Application-oriented University Intellectual Property
}

\author{
Yaomin Mei \\ Scientific Research Department \\ Zhuhai College of Jilin University \\ Zhuhai, Guangdong, China 519041
}

\author{
Xueshou Huang \\ Department of Admission and Employment \\ Zhuhai College of Jilin University \\ Zhuhai, Guangdong, China 519041
}

\author{
Junliang Kong \\ Department of International Trade and Finance \\ Zhuhai College of Jilin University \\ Zhuhai, Guangdong, China 519041
}

\begin{abstract}
Intellectual property education is a national education to implement the national intellectual property strategy and promote the development of intellectual property. Because of the late beginning of China's intellectual property education, the weak consciousness of application-oriented university intellectual property, little attention from the leaders, the lack of consensus education, simple curriculum design, lack of qualified teachers and outdated education concept, so the cultivation quality of intellectual property talent is not high. This paper explores the talent cultivation mode of innovative practice teaching from the perspectives of construction of doubleprofessionally-titled faculty, creating campus culture of intellectual property by both the university and enterprises, driving the case teaching and discussion teaching, professional background and vocational training and intellectual property practice simulation, etc.
\end{abstract}

Keywords-application-oriented university; intellectual property; education

\section{INTRODUCTION}

Application-oriented university is an undergraduate education, and was first built in the 1980s, meeting the needs of China's economic and social development under the new situation of higher education, with laying emphasis on practical teaching and training applied talents as the schoolrunning orientation, to construct new discipline direction, specialty structure, curriculum system, and update the teaching contents, teaching links, teaching methods and means, to comprehensively improve the teaching level, and cultivate the high quality, applied and integrated talents with strong social adaptation ability and competitiveness. In an age of science and technology innovation, colleges and universities are the important places of knowledge production and spreading, and the education of intellectual property has become a driving force for the implementation of national intellectual property strategy. As the main force to cultivate the applied and integrated talents, application-oriented university shall strengthen the education of intellectual property, to promote the discipline construction in colleges and universities, and improve the cultivation ability of intellectual property talents, which is of vital significance for promoting national economic development.

\section{IMPORTANCE OF INTELLECTUAL PROPERTY EDUCATION}

The Several Opinions on Further Strengthening the Work of Intellectual Property in Colleges and Universities as jointly issued by the Ministry of Education and the State Intellectual Property Office in 2004, requires the colleges and universities to add the contents of intellectual property into relevant courses such as Fundamentals of Law, and actively create conditions to offer intellectual property courses separately for undergraduates and postgraduates. The Outline of the National Intellectual Property Strategy as issued by the State Council in 2008, proposed to list "strengthening the construction of intellectual property talent team" as one of the major steps in achieving the goal of intellectual property strategy in China, and pointed out to involve intellectual property education into the quality education system of college students.

Intellectual property education is to better improve people's intellectual property awareness and improve the intellectual property creation, application, protection and management capability, to teach legal knowledge, legal system and culture of intellectual property, and to cultivate high-level professional talents in the field of intellectual property. Application-oriented university should strengthen the intellectual property education for college students and improve the comprehensive quality of personnel training based on training students' innovative ability, to realize the characteristics of running a school, and deliver more comprehensive talents for the society as well as promote economic and social development. 


\section{CURRENT SitUATION OF INTELLECTUAL PROPERTY EDUCATION}

\section{A. Starting Late with A Narrow Range}

In 2008, after the Outline of the National Intellectual Property Strategy was introduced, the Ministry of Education decided to open up the public course of Intellectual Property Law for the professional masters in colleges and universities nationwide; in 2009, opened up the public optional course of intellectual property for the undergraduates in science and engineering colleges; and in 2012, added the specialty of Intellectual Property Law for the undergraduates in the category of law. Since then, the research-oriented colleges gradually open up the intellectual property courses or professional courses, and the students start to have an understanding of intellectual property. Thus the intellectual property education was improved, and the talent cultivation system of intellectual property specialty was established preliminarily. Through the survey of undergraduate students' knowledge about intellectual property that made in 10 application-oriented universities in Guangdong, among the surveyed 300 students, only $70 \%$ of the students have heard of intellectual property, $40 \%$ of the students understand the connotation of intellectual property, $15 \%$ of the students learn intellectual property by themselves or have attended such classes, and $10 \%$ of the students know the importance that intellectual property is closely related to such problems as national development and economic growth. It can be seen that the intellectual property education hasn't been fully popularized in China, and it is only limited to the professional education of key colleges and universities.

\section{B. Divorce between Intellectual Property Talent Cultivation and Society}

The current intellectual property talent cultivation in colleges and universities in China only pays attention to theory but neglect practice, focusing on the teaching of intellectual property concept, legal knowledge and related theory knowledge, but without practical experience. The students cultivated by such method will have difficulty in dealing with intellectual property disputes arising in the course of business processing. China Intellectual Property News once reported that "Huawei reserves a seat for the talents, but there is a lack of such talents", illustrating Huawei's urgent demand for intellectual property talents, but it is hard to hire such interdisciplinary talents who know both technology and the law, and also familiar with international and domestic intellectual property. According to statistics, since 1998, when the Patent Agent Test was implemented in China till the end of 2014, 148671 people had taken the test, and 18972 people passed; by the end of 2015, there were more than 5000 people who have both the layer qualification certificate and patent agent qualification certificate nationwide. Less than $50 \%$ of the students who graduated from intellectual property specialty can find the jobs related to intellectual property. The society seeks intellectual property talents with eagerness, but the intellectual property professional graduates are unable to find a related job.

\section{Limitations to Vocational Education of Intellectual Property}

Vocational education of intellectual property is mainly refers to the training and examination education for the staff in the field of intellectual property. Most of the vocational education of intellectual property in China remains the training on senior management of the enterprise and various agents of intellectual property. Through training, their theory knowledge is enriched, the management level of intellectual property is improved, but lack of the intellectual property training targeted for the scientific and technical personnel. Senior staffs of the enterprise pay attention to management, and most of them are specialized in humanities \& social sciences without engineering background, and are not familiar with the creation, application, protection and management of the patented technology, which cannot really promote the rapid development of science and technology development and intellectual property. At present, there are mainly the following categories of professional qualifications of intellectual property: legal profession qualification certificate, patent agents, intellectual property planner, intellectual property management engineer (cancelled in 2014), the trademark agent qualification certificate of Chinese trademark association, copyright agent qualification certificate of copyright administration, etc. But as for the patent agent, the training is only targeted for the students specialized in science and engineering; the legal profession qualification certificate is targeted for the undergraduates specialized in law or the undergraduates who are not specialized in law but have professional knowledge of law; only the intellectual property planner is the complex intellectual property talent.

\section{PROBLEMS IN THE EDUCATION OF INTELLECTUAL PROPERTY IN APPLICATION-ORIENTED UNIVERSITY}

\section{A. Lack of Consensus Education with Simple Curriculum Setting}

Intellectual property education is a discipline combining theoretical level and practical ability, having certain relevance and consistency with ideological and political education as well as quality education. Many application-oriented universities have no in-depth understanding on intellectual property education, and only teach intellectual property as a kind of civil law, without considering the correlation with other professional knowledge. The optional course of intellectual property theory is only opened for a few professional students, moreover, the course setting is simple and the teaching scope is small, without opening the optional course or professional course in the whole school. For example, only set up the theoretical course of Intellectual Property Basis for students majoring in science and engineering or open up the theoretical course of Intellectual Property Law for the students specialized in management or law, and even some application-oriented universities haven't opened up the course of intellectual property. Currently, only a few applicationoriented universities have involved intellectual property into the general education program of undergraduate course, and there is a big problem in intellectual property talent cultivation, for example, the literary arts students are not familiar with 
copyright, students of science and engineering are not familiar with patent right, and business students not familiar with the trademark rights and other issues.

\section{B. Lack of Qualified Teachers with Outdated Educational Concept}

In application-oriented universities, most teachers of intellectual property are graduated from the specialty of law, and they just pay attention to theory and ignore the practice in teaching. Teachers tend to teach more relevant theoretical knowledge and frontier knowledge of intellectual property, but rarely conduct procedural and practical teaching. As there is certain conflict between the theory dominant background of liberal arts and the practice guidance of science and engineering, the intellectual property teachers with liberal arts background have difficulty in entering into science and engineering. Moreover, many of the reference textbooks for intellectual property teaching are targeted for graduate education, so there is no course suitable for unified intellectual property education for applied undergraduate students. In the process of teaching intellectual property, teachers still apply common law teaching mode, of which the teaching method is simple without targeted purpose, and teaching contents are less and focusing on law while ignoring practice, the knowledge updating is slow, which cannot adapt to the new forms and new changes in the field of intellectual property.

\section{School Leaders Are Indifferent to Intellectual Property}

The course of intellectual property education has a late starting, as it is opened up gradually in application-oriented universities in recent years. Previously, students can only learn about intellectual property through newspapers, online media and other channels. Application-oriented universities generally pay no enough attention to intellectual property, many school administrators have less awareness of intellectual property, as they generally believe that the focus of intellectual property education is to cultivate high-level technical talent, and think that intellectual property is the course for students majored in law and has nothing to do with the other specialties, ignoring the basic popularization and education for students to some extent. Intellectual property is a kind of general term of intellectual achievements, involving law, economics, management science, literature, art and other fields. In terms of intellectual property education, application-oriented universities haven't fully considered the simplicity of students' subject and knowledge background. In teaching of intellectual property, the traditional teaching model of law is adopted to simply add it together with other subject, resulting students having a vague concept of intellectual property, thinking the intellectual property course is boring, having no enough understanding of their own intellectual property theory, thus making students' learning enthusiasm is not high, paying no attention to the learning of intellectual property, which has influenced the promotion of intellectual property education.

\section{COUNTERMEASURES TO STRENGTHEN INTELLECTUAL PROPERTY EDUCATION IN APPLICATION-ORIENTED} UNIVERSITY

\section{A. Improve Intellectual Property Education System and Mechanism}

Intellectual property is an independent discipline; application-oriented universities should attach importance to the important position of intellectual property education in innovation and entrepreneurship, develop and improve the system of intellectual property education in school, establish intellectual property incentive mechanism, and set up an independent department to take charge of internal organization teaching and external communication. The competent department shall formulate the cultivation plan of intellectual property education according to characteristics of the school to optimize teaching resources, and prepare the stage plan for the school's intellectual property education, set up the reasonable and scientific course of intellectual property, and establish a long-term stable education period according to characteristics of students of different disciplines and grades. At the same time, propose the requirement of teachers in the plan that teachers shall go deeper into the concept and push forward practice, and turn to professional talents cultivation from general talents cultivation. In setting up the curriculum, application-oriented universities can refer to the successful practice of foreign colleges and universities to establish the complementary system of compulsory courses and optional courses. Open up the course of Intellectual Property Basis for freshman and sophomore students, to consolidate the basic knowledge; open up the course of Intellectual Property Practice for junior and senior students majored in science and engineering, such as the series courses of patent right, trademark right, copyright and so on.

\section{B. Establish Double-Professionally-Titled Intellectual Property Teachers}

In the implementation of intellectual property education, intellectual property teachers are the main body and the key to promote education. The strength of teachers will influence teaching quality, and directly affects the development of intellectual property education. Application-oriented universities shall establish such intellectual property teachers of "Relying mainly on professional teachers, and assisted by part-time teachers, backed by visiting professors" according to the school's subject characteristics and teaching tasks. Introduce in the teachers with science and engineering background as appropriate in combination with the teachers' knowledge structure of intellectual property education in application-oriented universities. And provide related knowledge training to the teachers with liberal arts background to enrich their knowledge and improve the ability of theory teaching. And encourage teachers to participate in the training and examination of intellectual property professional certification, and give appropriate subsidies to the teachers who have passed the exam, encourage teachers to take a temporary post in intellectual property institution to exercise, thus to enrich practical experience of intellectual property, improve teaching practice ability, so as to cultivate a batch of double-professionally-titled intellectual property teacher who 
only own teaching ability but also have professional practice experience. Engage the high-level personnel with profound practical experience from the intellectual property company or agency for the training, and open up related courses or seminar, to integrate their practical experience to classroom teaching, and alleviate the current situation of shortage of university intellectual property teachers.

\section{Exploration on New Mode of Intellectual Property Education}

Intellectual property rights education mode directly affects students' interest and acceptance ability in the teaching process of intellectual property. Application-oriented universities should explore new teaching mode and open up innovative practice teaching. Innovative practice teaching requires the intellectual property teaching to introduce in case teaching and video teaching based on breakthrough of traditional teaching mode to concretize the abstract knowledge, and arouse students' interest. Moreover, it also requires the teaching of "going out", to carry on the practice of production, learning and research, to strengthen the students' intellectual property training.

1) Construct the education mode of campus culture jointly created by university and enterprise

Through the activities of university-enterprise cooperation in scientific research, set up the intellectual property contests for students, vigorously promote, encourage and support the student to participate in scientific research, cultivate the spirit of advocating science, strengthen the consciousness of intellectual property, and arrange the rewarded students to intellectual property agency as trainee for 1-3 months.

2) Adopt the teaching mode of task driven teaching, case teaching and discussion teaching

In the patent practice course teaching, take the actual case of patent filing as an example, distribute the interpretation of patent document writing points, and make students in groups, asking them to write patent application materials through network query and mutual discussion.

3) Establish the talent training mode of "professional background + vocational training"

Cooperate with the training institutions who have the right to issue the professional certificate related to intellectual property, regularly organize intellectual property professional training and exam, encourage and support the students majored in science and engineering with a solid foundation and high level of foreign language to participate in the training and examination, and offer certain test subsidies to the students who have passed the exam.

4) Adopt the talent training mode of intellectual property practice simulation

Establish a simulated intellectual property company in the innovation and entrepreneurship education base in the school which shall be taken charge by the full time intellectual property teachers, to arrange those students who have interest in intellectual property and have certain intellectual property basis to practice in the simulation company, to conduct simulation processing of intellectual property practice and exercise the ability about intellectual property affairs.

\section{REFERENCES}

[1] Wang Yuhong, Xu Pin. Research on Intellectual Property Education Countermeasures in Universities of Science and Engineering [J]. Heilongjiang Researches on Higher Education, 2015(6).

[2] Wang Yuqiu, Gu Chengqing. Analysis of the Necessity and Paths for Strengthening Intellectual Property Education in Colleges [J]. Technology and Innovation, 2014 (11).

[3] Wang Qinglin. Several Considerations on Cultivation Modes of Innovative Applied Undergraduate Talents [J]. China University Teaching, 2013(6).

[4] Yuyan, Huang Shengkai. Current Situation of Intellectual Property Education in Colleges and its Countermeasures [J]. Education and Career,2011(29).

[5] Tai Xinmin. Procedure of Intellectual Property Education Integrating School and Enterprise, Point and Sphere in Higher Vocational Colleges and the Practices [J]. Vocational and Technical Education, 2011(14)

[6] Guo Dezhong. Analysis of Intellectual Property Education in Colleges [J]. Education and Career, 2007(11).

[7] Zou Xiaohong, Xu Jing. Study on Current Situation of Intellectual Property Education in Colleges [J]. Journal of Changchun University of Science and Technology (Social Science Edition),2011(9).

[8] Ma Xiushan. Reflecting on China's Intellectual Property Education and its Countermeasures [J]. Intellectual Property, 2007(02). 